Jurnal Ners Volume 4 Nomor 1 Tahun 2020 Halaman 1 - 6

JURNAL NERS

Research \& Learning in Nursing Science

http://journal.universitaspahlawan.ac.id/index.php/ners

\title{
HUBUNGAN KASIH SAYANG DIRI SENDIRI TERHADAP STATUS KESEHATAN MENTAL PADA LANSIA DI KELURAHAN AIR TIRIS KECAMATAN KAMPAR
}

\author{
Alini $^{1}$, Siti Ardianti ${ }^{2}$ \\ Program Studi Sarjana Keperawatan \\ Universitas Pahlawan Tuanku Tambusai \\ Alini_09@yahoo.com
}

\begin{abstract}
Abstrak
Status kesehatan mental adalah suatu keadaan jiwa atau keadaan psikologis yang terganggu ditandai dengan masalah-masalah yang ada dalam diri sendiri (internal) dan masalah-masalah yang ada di lingkungan luar dirinya (eksternal). Salah satu penyebab status kesehatan mental terganggu adalah kasih sayang diri sendiri. Tujuan penelitian ini adalah untuk mengetahui adakah hubungan kasih sayang diri sendiri terhadap status kesehatan mental pada lansia di Kelurahan Air Tiris Kecamatan Kampar. Penelitian ini adalah penelitian kuantitatif dengan rancangan cross sectional. Sampel dalam penelitian ini adalah sebagian lansia yang berada di Kelurahan Air Tiris Kecamatan Kampar yang berjumlah 79 orang dengan teknik pengambilan sampel simple random sampling. Pengolahan data menggnakan uji chi-square. Hasil penelitian didapatkan bahwa tidak terdapat hubungan yang signifikan antara kasih sayang diri sendiri terhadap status kesehatan mental pada lansia di Kelurahan Air Tiris Kecamatan Kampar ( $p$ value $>\alpha(0,05)$. Hasil penelitian ini diharapkan dapat dimanfaatkan oleh lansia untuk harus lebih meningkatkan ibadah dan mendekatkan diri kepada Allah SWT dan mengikuti kegiatan-kegiatan yang dilakukan oleh kelompok-kelompok lansia seperti pengajian ibuibu.
\end{abstract}

\section{Kata Kunci: Lansia, Kasih Sayang Diri Sendiri, Status Kesehatan Mental}

\begin{abstract}
Mental health status is a mental state or psychological state that is disturbed marked by problems that exist within oneself (internal) and problems that exist in the external environment (external). One cause of disturbed mental health status is self-affection. The purpose of this study was to determine whether there is a relationship of self-affection to the mental health status of the elderly in Air Tiris Village, Kampar District. This research is a quantitative study with cross sectional design. The sample in this study were some of the elderly who were in Air Tiris Village, Kampar District, totaling 79 people with simple random sampling technique. Data processing uses the chi-square test. The results showed that there was no significant relationship between self-affection towards mental health status in the elderly in Air Tiris Village, Kampar Subdistrict ( $p$ value $>\alpha(0.05)$. The results of this study were expected to be used by the elderly to further improve worship. and get closer to Allah SWT and follow the activities carried out by elderly groups such as mothers' recitation.
\end{abstract}

Keywords: Elderly, Self-Compassion, Mental Health Status

@ Jurnal Ners Prodi Sarjana Keperawatan \& Profesi Ners FIK UP 2020

\footnotetext{
$\triangle$ Corresponding author :

Address : Jl. Tuanku Tambusai No. 23 Bangkinang

Email : alini_09@yahoo.com

Phone : 085265591056
} 


\section{PENDAHULUAN}

Laju perkembangan penduduk dunia termasuk Indonesia saat ini menuju proses penuaan yang di tandai dengan meningkatnya jumlah dan proporsi penduduk lanjut usia (Andini, 2013 dalam Saraisang, dkk. 2018). Populasi lansia di Dunia dari tahun ke tahun semakin meningkat, pada tahun 2015 dan 2030 jumlah orang lanjut usia di seluruh dunia meningkat menjadi $56 \%$, dari 901 juta menjadi lebih dari 1,4 miliar. Pada tahun 2030, jumlah orang berusia 60 ke atas akan melebihi usia muda yang berusia 15 sampai 24 tahun (UNIDOP, 2017 dalam Gusa, dkk. 2018).

Jumlah penduduk lansia di Indonesia berdasarkan data proyeksi penduduk pada tahun 2017 terdapat 23,66 juta jiwa dari populasi penduduk sebanyak 136,86 jiwa per $\mathrm{km}^{2}$ (Kementrian Kesehatan RI, 2018). Berdasarkan Badan Pusat Statistik (BPS) jumlah lansia di Provinsi Riau pada tahun 2017 terdapat 288.911 jiwa dari jumlah populasi penduduk sebanyak 5.766.241 jiwa (Badan Pusat Statistik, 2018). Sedangkan jumlah lansia di Provinsi Riau pada tahun 2018 terdapat 306.201 dari jumlah populasi penduduk sebanyak 6.074.068 jiwa (Data GIS Dukcapil Kemendagri Penduduk, 2018).

Berdasarkan Profil Kesehatan Kabupaten Kampar pada tahun 2014 jumlah lansia sebanyak 12.496 jiwa, pada tahun 2015 jumlah lansia sebanyak 25.367 jiwa, pada tahun 2016 jumlah lansia sebanyak 28.827 jiwa dan pada tahun 2017 jumlah lansia meningkat sebanyak 35.289 jiwa dari jumlah populasi penduduk sebanyak 785.943 jiwa (Kementerian Kesehatan RI, 2018). Sedangkan jumlah lansia Kabupaten Kampar pada tahun 2018 sebanyak 35.677 jiwa dari jumlah populasi penduduk sebanyak 748.956 jiwa (Data GIS Dukcapil Kemendagri Penduduk, 2018).

Jumlah lansia dengan tiga peringkat tertinggi di Kabupaten Kampar berada pada Kecamatan Tapung sebanyak 3,532 jiwa, Kecamatan Siak Hulu sebanyak 3,203 jiwa, dan Kecamatan Kampar sebanyak 3,202 jiwa. Dari ketiga Kecamatan tersebut jumlah lansia yang menduduki peringkat ketiga berada pada Kecamatan Kampar dengan jumlah lansia sebanyak 3,202 jiwa.

Jumlah lansia tertinggi di Kecamatan Kampar berada di Kelurahan Air Tiris yaitu 371 jiwa. Besarnya jumlah penduduk lansia menjadi beban jika lansia memiliki masalah penurunan kesehatan yang berakibat pada peningkatan biaya pelayanan kesehatan (Badan Pusat Statistik, 2015).

Meningkatnya jumlah penduduk usia lanjut (lansia) tentu menimbulkan masalah terutama dari segi kesehatan dan kesejahteraan lansia. Masalah tersebut jika tidak ditangani akan berkembang menjadi masalah yang lebih kompleks. Masalah yang kompleks pada lansia baik dari segi fisik, mental, dan sosial berkaitan dengan kesehatan dan kesejahteraan mereka (Notoadmodjo, 2011 dalam Widia, 2017). Menurut Undang - Undang Republik Indonesia 13 tahun 1998 tentang Kesejahteraan Lanjut Usia, yang dimaksud dengan Lanjut Usia (lansia) adalah seseorang yang telah mencapai usia 60 tahun ke atas (Aspiani, 2014).

Ketidakmampuan individu dalam menghadapi suatu masalah dapat menyebabkan individu mengalami gangguan kesehatan jiwa, seperti cemas dan stres. Stres dapat dialami oleh semua orang dalam rentang kehidupannya (Varcarolis, 2010 dalam Sarifhatul, 2017). Seorang lansia dalam kehidupannya yang banyak mengalami berbagai masalah kesehatan mental maka dapat menimbulkan perasaan yang tidak enak, gelisah dan takut, sehingga lansia merasa dirinnya tidak berguna dan merasa telah gagal di masa tuanya. Kesehatan mental adalah suatu keadaan jiwa atau keadaan psikologis yang menunjukan kemampuan seseoarang untuk mengadakan penyesuaian diri atau pemecahan masalah-masalah yang ada dalam diri sendiri (internal) dan masalah-masalah yang ada dalam lingkungan luar dirinya (eksternal) (Hanurawan, 2012 dalam Konna, 2017).

Rasa belas kasih atau kasih sayang diri sendiri (Self compassion) sangat bermanfaat untuk orang yang memiliki masalah kesehatan mental. Oleh karena itu, lansia harus menyayangi dan mengasihi diri sendiri agar mampu mengatasi masalah kesehatan mental yang dialami.

Menurut Hidayati dan Maharani (2013, dalam Adine, 2018), Self compassion merupakan kombinasi antara motivasi, kognisi, dan perilaku yang menunjukkan kasih sayang saat mengalami kesulitan dan penderitaan, dimana kasih sayang tersebut ditujukan kepada diri sendiri.

Penelitian yang dilakukan oleh Kim dan Ko yaitu The impact of self-compassion on mental health, sleep, quality of life satisfaction among order adults diperoleh hasil bahwa kasih sayang diri sendiri memiliki hasil yang positif dengan kesehatan mental, 
gangguan tidur dan kualitas hidup diantara kalangan orang lansia. Penelitian lain yang dilakukan oleh Adine, dkk, 2018 menemukan bahwa selfcompassion berhubungan positif secara signifikan dengan kualitas hidup terkait kesehatan.

Berdasarkan data diketahui bahwa Kecamatan Kampar menduduki peringkat ketiga dengan jumlah lansia sebanyak 3,202 orang dalam penelitian ini peneliti memutuskan untuk menjadikan Kecamatan Kampar sebagai tempat penelitiannya karena Kampar memiliki beberapa keuntungan diantaranya: (1) Tempat lebih mudah dijangkau oleh peneliti, (2) Waktu yang digunakan dalam penelitian juga lebih sedikit, (3) Biaya transfortasi lebih hemat.

Berdasarkan studi pendahuluan pada tanggal 24 April 2019 di Kelurahan Air Tiris Kecamatan Kampar terhadap 10 orang lansia di Kelurahan Air Tiris didapat data 9 orang (90\%) lansia mengatakan dirinya cemas, takut dan kuatir dan 1 orang (10\%) lansia mengatakan dirinya bahagia dalam kehidupannya karena setiap aktivitas yang dilakukan saat ini sudah membuat dirinya bahagia.

Berdasarkan latar belakang diatas peneliti tertarik melakukan penelitian mengenai "Hubungan Kasih Sayang Diri Sendiri Terhadap Status Kesehatan Mental Pada Lansia di Kelurahan Air Tiris Kecamatan Kampar Tahun 2019”.

\section{METODE}

\section{Desain Penelitian}

Desain penelitian ini adalah analitik dengan rancangan cross sectional (potong lintang), yaitu setiap variabel diobservasinya hanya satu kali saja dan pengukuran masing-masing variabel dilakukan pada waktu yang sama (Notoatmodjo, 2010).

\section{Lokasi dan Waktu Penelitian}

Penelitian ini dilakukan pada lansia di Kelurahan Air Tiris Kecamatan Kampar, pada tanggal 11 s/d 19 Juni 2019.

\section{Populasi}

Populasi adalah keseluruhan objek penelitian atau objek yang diteliti (Notoatmodjo, 2012). Populasi dalam penelitian ini adalah seluruh lansia di Kelurahan Air Tiris sebanyak 371 orang.

\section{Sampel}

Sampel adalah sebagian dari jumlah dan karakteristik yang dimiliki oleh populasi
(Notoatmodjo, 2012). Sampel dalam penelitian ini adalah lansia di Kelurahan Air Tiris Kecamatan Kampar yang dianggap dapat mewakili seluruh polulasi sebanyak 79 orang. Teknik pengambilan sampel dalam penelitian ini menggunakan teknik purposive sampling, yaitu pengambilan sampel secara purposive didasarkan pada suatu pertimbangan tertentu yang dibuat oleh peneliti sendiri, ciri atau sifat-sifat populasi yang sudah diketahui sebelumnya (Notoatmodjo, 2012).

\section{Alat Pengumpulan Data}

Alat yang digunakan dalam penelitian ini adalah kuesioner. Kuesioner berisikan pertayaanpertanyaan tertutup, yaitu angket yang disajikan dalam bentuk sedemikian rupa sehingga responden diminta untuk memilih salah satu jawaban yang sesuai dengan memberikan tanda checklist $(\checkmark)$.

Pernyataan untuk menilai hubungan kasih sayang diri sendiri terhadap status kesehatan mental pada lansia menggunakan skala Likert, jumlah pernyataan untuk mengukur kasih sayang lansia berjumlah 26 pernyataan. Uji validitas kuesioner kasih sayang ini tidak perlu dilakukan oleh peneliti karena alat ukur yang digunakan sudah baku dengan cronbach $\alpha$ untuk SCS adalah 0,81 yaitu menggunakan Skala Self Compassion (SCS) yang dikembangkan oleh Neff yang telah digunakan peneliti sebelumnya yaitu Kim \& Ko (2017) yang meneliti pengaruh kasih sayang diri sendiri terhadap status kesehatan mental, tidur, kualitas hidup, dan kepuasan hidup pada lansia di Korea.

Untuk mengukur status kesehatan mental diukur dengan Self Questionnaire (SQR) merupakan status emosional individu, dimana SQR terdiri dari 20 pertanyaan yang mempunyai pilihan jawaban "ya" dan "tidak". Alat ukur yang digunakan untuk mengukur status kesehatan mental diukur dengan Self Questionnaire (SQR) yang telah digunakan peneliti sebelumnya yaitu Konna (2017).

\section{Analisa Data}

Analisa data yang digunakan adalah analisa univariat dan analisa bivariat. Analisa univariat bertujuan untuk menjelaskan atau mendeskripsikan karakteristik setiap variabel penelitian. Pada umumnya dalam analisis ini hanya menghasilkan distribusi frekuensi dan persentase dari setiap variabel. Analisa bivariat digunakan untuk melihat hubungan antara variabel independen dengan 
variabel dependen. Analisa bivariat dalam penelitian ini menggunakan uji chi-square $\left(\mathrm{X}^{2}\right)$ dengan menggunakan tingkat kepercayaan 95\% dengan menggunakan sistem komputerisasi.

\section{HASIL DAN PEMBAHASAN}

\section{Analisis Univariat}

Analisa data dilakukan secara analisis univariat yaitu dengan menilai persentase data yang dikumpulkan dan disajikan dalam tabel distribusi frekuensi analisa data, dengan karakteristik lansia yang meliputi jenis kelamin, pendidikan, usia, dan pekerjaan. Berdasarkan hasil penelitian diketahui bahwa dari 79 lansia yang berada di Kelurahan Air Tiris Kecamatan Kampar, sebagian besar berjenis kelamin perempuan dengan jumlah 56 orang (70,9\%), sebagian besar memiliki tingkat pendidikan SD dengan jumlah 54 orang $(68,4 \%)$, sebagian besar berada pada rentang usia 60-74 tahun dengan jumlah 59 orang $(74,7 \%)$, dan sebagian besar lansia tidak bekerja dengan jumlah 51 orang $(64,4 \%)$. Kasih sayang diri sendiri pada lansia yang berada di Kelurahan Air Tiris Kecamatan Kampar, sebagian besar berada pada kasih sayang positif dengan jumlah 49 orang (62\%). Status kesehatan mental pada lansia yang berada di Kelurahan Air Tiris Kecamatan Kampar sebagian besar berada pada kategori terganggu dengan jumlah 54 orang $(68,4 \%)$.

\section{Analisa Bivariat}

Analisis bivariat dilakukan untuk melihat ada tidaknya hubungan antara dua variabel, yaitu variabel independen (kasih sayang diri sendiri) dan variabel dependen (status kesehatan mental). Uji statistik yang digunakan dalam penelitian ini adalah uji chi-square.

Tabel 1 :Hasil Analisa Hubungan Kasih Sayang Diri Sendiri Terhadap Status Kesehatan Mental Pada Lansia di Kelurahan Air Tiris Kecamatan Kampar Tahun 2019

\begin{tabular}{|c|c|c|c|c|c|c|c|c|}
\hline \multirow{3}{*}{ No } & \multirow{3}{*}{$\begin{array}{c}\text { Kasih } \\
\text { Sayang } \\
\text { Diri } \\
\text { Sendiri }\end{array}$} & \multicolumn{4}{|c|}{ Status Kesehatan Mental } & \multirow{2}{*}{\multicolumn{2}{|c|}{ Total }} & \multirow{3}{*}{$\begin{array}{c}\mathrm{P} \\
\text { Value }\end{array}$} \\
\hline & & \multicolumn{2}{|c|}{$\begin{array}{c}\text { Tidak } \\
\text { Terganggu } \\
\end{array}$} & \multicolumn{2}{|c|}{ Terganggu } & & & \\
\hline & & $\mathrm{N}$ & $\%$ & $\mathrm{~N}$ & $\%$ & $\mathrm{~N}$ & $\%$ & \\
\hline 1 & Positif & 15 & 30,6 & 34 & 69,4 & 49 & 100 & 0,801 \\
\hline 2 & Negatif & 10 & 33,3 & 20 & 66,7 & 30 & 100 & \\
\hline & Total & 25 & 31,6 & 54 & 68,4 & 79 & 100 & \\
\hline
\end{tabular}

Dari tabel 1 di atas diketahui hasil tabulasi silang (crosstabs) antara kasih sayang diri sendiri terhadap status kesehatan mental pada lansia menunjukkan bahwa dari 49 responden dengan kasih sayang positif terdapat 15 responden $(30,6 \%)$ yang kesehatan mentalnya tidak terganggu dari 30 responden dengan kasih sayang negatif terdapat 10 responden $(33,3 \%)$ yang status kesehatan mentalnya tidak terganggu.

Hasil analisa statistik diperoleh nilai signifikan $p$ value $=0,801$ ( $p$ value $>\alpha 0.05)$. Hal ini dapat diartikan bahwa tidak terdapat hubungan yang signifikan antara kasih sayang diri sendiri terhadap status kesehatan mental pada lansia di Kelurahan Air Tiris Kecamatan Kampar.

\section{PEMBAHASAN}

Dari hasil penelitan ini, diketahui bahwa tidak terdapat hubungan kasih sayang diri sendiri terhadap status kesehatan mental pada lansia di Kelurahan Air Tiris Kecamatan Kampar tahun 2019, menunjukkan bahwa dari 49 responden dengan kasih sayang positif terdapat 15 responden $(30,6 \%)$ yang kesehatan mentalnya tidak terganggu.dari 30 responden dengan kasih sayang negatif terdapat 10 responden $(33,3 \%)$ yang status kesehatan mentalnya tidak terganggu.

Kesehatan mental adalah suatu keadaan jiwa atau keadaan psikologis yang menunjukkan kemampuan seseoarang untuk mengadakan penyesuaian diri atau pemecahan masalah-masalah yang ada dalam diri sendiri (internal) dan masalahmasalah yang ada dalam lingkungan luar dirinya (eksternal) (Hanurawan, 2012 dalam Konna, 2017). Daradjat menyatakan kesehatan mental adalah terwujudnya fungsi kejiwaan dan terciptanya penyesuaian diri antara manusia dengan dirinya sendiri berdasarkan keimanan dan ketakwaan serta bertujuan untuk mencapai hidup yang bermakna dan bahagia dunia dan akhirat (Syaharia, 2008 dalam Konna, 2017).

Faktor-faktor yang dapat memicu terganggunya status kesehatan mental diantaranya yaitu kasih sayang diri sendiri, kesehatan fisik, faktor demografi (umur, jenis kelamin, pendidikan, status perkawinan dan pekerjaan), faktor psikologi (pengalaman awal, proses pembelajaran, dan kebutuhan), faktor sosial budaya (interaksi sosial dan keluarga), dan faktor lingkungan. Hasil penelitian ini diketahui bahwa tidak terdapat hubungan kasih sayang diri sendiri terhadap status kesehatan mental pada lansia di Kelurahan Air Tiris Kecamatan Kampar tahun 2019. Peneliti berasumsi ada beberapa faktor lain yang 
mempengaruhi status kesehatan mental pada lansia.

Pertama, jenis kelamin, didiagnostik gangguan mental adalah sama untuk semua jenis kelamin, namun wanita lebih rentan terkena gangguan mental emosional karena disebabkan perubahan hormonal dan perbedaan karakteristik antara laki-laki dan perempuan, selain perubahan hormonal, karakteristik wanita lebih mengedepankan emosional daripada rasional juga berperan. Ketika menghadapi suatu masalah wanita cenderung menggunakan perasaan (Konna, 2017). Penelitian yang dilakukan oleh peneliti dilihat berdasarkan karakteristik jenis kelamin responden wanita lebih rentan mengalami gangguan status kesehatan mental yaitu sebanyak 23 responden yang berjenis kelamin perempuan dari 34 responden yang status kesehatan mentalnya terganggu. Penelitian ini sejalan dengan penelitian (Sutinah, 2017) tentang hubungan pendidikan, jenis kelamin dan status perkawinan dengan depresi pada lansia menunjukkan jumlah lansia perempuan yang mengalami depresi lebih mendominasi dibandingkan jumlah lansia laki-laki yang mengalami depresi.

Kedua, tingkat pendidikan, pendidikan yang makin tinggi dapat menghasilkan keadaan sosial ekonomi yang makin baik dan kemandirian yang makin mantap, dari penelitian Boedhi Darmojo tahun 1992 di Semarang didapatkan bahwa tingkat pendidikan seseorang usia lanjut berbanding positif lansung dengan tingkat kesehatannya (Konna, 2017). Penelitian yang dilakukan oleh peneliti dilihat berdasarkan karakteristik tingkat pendidikan responden lansia yang berpendidikan rendah lebih banyak mengalami gangguan status kesehatan mental daripada yang berpendidikan tinggi. Penelitian ini sejalan dengan penelitian (Sutinah, 2017) tentang hubungan pendidikan, jenis kelamin dan status perkawinan dengan depresi pada lansia menunjukkan lansia yang berpendidikan rendah lebih banyak terkena depresi daripada yang berpendidikan tinggi. Pendidikan dapat mempengaruhi perilaku seseorang. Semakin tinggi pendidikan seseorang, maka ia akan semakin mudah menerima informasi sehingga semakin banyak pula pengetahuan yang dimiliki. Di samping itu, pendidikan juga merupakan awal dalam perkembangan kognitif, dimana kognitif tersebut dapat menjadi mediator antara suatu kejadian dan mood, sehingga kurangnya pendidikan dapat menjadi faktor resiko lansia menderita depresi (Stewart, 2010 dalam Sutinah, 2017).

Ketiga, status pekerjaan, kehilangan peran kerja sering memiliki dampak besar bagi orang yang telah pensiun. Identitas biasanya berasal dari peran kerja, sehingga individu harus membangun identitas baru pada pensiun. Mereka juga kehilangan struktur pada kehidupan harian saat mereka tidak lagi memiliki jadwal kerja. Interaksi sosial dan interpersonal yang terjadi pada lingkungan kerja juga telah hilang. Sebagai penyesuaian lansia harus menyusun jadwal yang bermakna dan jaringan sosial pendukung (Perry, 2009 dalam Suyoko, 2012). Penelitian yang dilakukan oleh peneliti dilihat berdasarkan karakteristik status pekerjaan responden lansia yang tidak bekerja lebih rentan mengalami gangguan status kesehatan mental daripada lansia yang bekerja.

Keempat, status perkawinan, seseorang yang berstatus duda/janda atau tidak menikah berisiko hidup sendiri, dimana hidup sendiri juga merupakan faktor risiko terjadinya depresi pada lansia (Maryam, 2012). Lansia yang masih memilki pasangan hidup akan memilki tempat untuk saling berbagi dan mendukung dalam menghadapi masa tua sehingga memiliki risiko depresi yang lebih rendah (Suardana, 2011). Dalam penelitian Sutinah (2017) tentang hubungan pendidikan, jenis kelamin dan status perkawinan dengan depresi pada lansia, proporsi depresi dalam penelitian ini ditemukan lebih tinggi pada lansia janda/duda atau tidak menikah.

Kelima, kesehatan fisik, lansia tidak sehat secara fisik mempunyai peluang tidak sehat secara mental 20 kali lebih tinggi daripada lansia yang sehat. Hasil suatu survey yang dilakukan di 60 negara dengan jumlah responden sebanyak 245.404 orang menyatakan bahwa sebanyak 9,3$2,3 \%$ responden yang mempunyai satu atau lebih mengalami depresi..

\section{SIMPULAN}

1. Lansia yang berada di Kelurahan Air Tiris Kecamatan Kampar memiliki kasih sayang positif sebanyak 49 responden.

2. Lansia yang berada di Kelurahan Air Tiris Kecamatan Kampar dengan status kesehatan mentalnya terganggu sebanyak 34 responden. 
3. Tidak terdapat hubungan kasih sayang diri sendiri terhadap status kesehatan mental pada lansia di Kelurahan Air Tiris Kecamatan Kampar dengan nilai signifikan $p$ value $=0,801$

\section{SARAN}

1. Bagi responden (Lansia) hendaknya dapat lebih meningkatkan ibadah dan mendekatkan diri kepada Allah SWT, mengikuti kegiatankegiatan yang dilakukan oleh kelompokkelompok lansia seperti pengajian ibu-ibu.

2. Pihak keluarga ikut serta dalam mengurangi masalah kesehatan mental, seperti keluarga memberikan dukungan, memperhatikan dan mendengarkan keluh kesah yang lansia alami serta mengajak liburan atau bermain bersama.

3. Penelitian selanjutnya diharapkan dapat melakukan penelitian lebih lanjut dengan lebih banyak variabel yang berhubungan dengan status kesehatan mental seperti faktor-faktor lain yang memicu status kesehatan mental terganggu pada lansia diantaranya: jenis kelamin, pendidikan, pekerjaan, status perkawinan, dan kesehatan fisik pada lansia.

\section{DAFTAR PUSTAKA}

Adine, Putri A, dkk. (2018). Peran Self Compassion Terhadap Kualitas Hidup Terkait Kesehatan Pada Remaja Di Jakarta.Prosiding Seminar Nasional 2018 Fakultas Psikologi Undip. https://www.researchgate.net. Diakses tanggal 10 Mei 2019.

Apsari, Theresia, C. (2018). Hubungan Antara Belas Kasih Dan Kompetensi Romantis Pada Remaja Penonton Drama Korea. Skripsi. Universitas Sanata Dharma Yogyakarta.

Badan Pusat Statistik Provinsi Riau. (2016). Provinsi Riau Dalam Angka. https://riau.bps.go.id. Diakses tanggal 10 Mei 2019.

Badan Pusat Statistik. (2015). Statistik Penduduk Lanjut Usia. https://www.bps.go.id. Diakses tanggal 10 Mei 2019.

Data Gis Dukcapil Kemendagri Penduduk. (2018). Visualidasi Data Kependudukan. https://gis.dukcapil.kemendagri.go.id.peta. Diakses tanggal 5 Mei 2019.

Gusa, Meiske, dkk. (2018). Hubungan Tingkat Demensia Dengan Konsep Diri Pada Lanjut Usia Di BPLU Senja Cerah Provinsi Sulawesi Utara. Jurnal
Keperawatan.https://ejournal.unsrat.ac.id. Diakses tanggal 5 Mei 2019.

Hidayat, A,Azis Alimul. (2014). Metode Penelitian Kebidanan Dan Teknik Analisis Data. Jakarta: Salemba Medika.

Kementerian Kesehatan RI. (2018). Profil Kesehatan Indonesia 2017. www.depkes.go.id. Diakses tanggal $10 \mathrm{Mei}$ 2019.

Konna, Suryanti. (2017). Hubungan Kesehatan Mental Dan Healthy Food Choicr Dengan Kejadian Hipertensi Pada Guru Sekolah Menengah Di Makassar Tahun 2017. Skripsi. Universitas Hasanuddin Makassar.

Mardalis, (2009). Metode Penelitian Suatu Pendekatan Proposal. Jakarta: PT Bumi Aksara.

Notoatmodjo, Soekidjo. (2012). Metode Penelitian Kesehatan. Jakarta: Rineka Cipta.

Notoatmodjo, Soekidjo. (2010). Metodologi Penelitian Kesehatan. Jakarta: Rineka Cipta.

Nursalam, (2015). Metodologi Penelitian Ilmu Keperawatan Pendekatan Praktis Edisi 4. Jakarta: Salemba Medika.

Saraisang, Cindy M, dkk. (2018). Hubungan Pelayanan Posyandu Lansia Dengan Tingkat Kepuasan Lansia Di Wilayah Kerja Puskesmas Ranomuut Kecamatan Paal Kota Manado. Jurnal Keperawatan. https:/ejournal.unsrat.ac.id. Diakses tanggal 5 Mei 2019. 